\title{
Enhancement of Balance in Strength, Ductility, and Stretch Flangeability by Two-Step Austempering in a 1000 MPa Grade Cold Rolled Bainitic Steel
}

\author{
Shuai Tang *, Huifang Lan *, Zhenyu Liu and Guodong Wang
}

Citation: Tang, S.; Lan, H.; Liu, Z.; Wang, G. Enhancement of Balance in Strength, Ductility, and Stretch Flangeability by Two-Step Austempering in a $1000 \mathrm{MPa}$ Grade Cold Rolled Bainitic Steel. Metals 2021, 11, 96. https://doi.org/ 10.3390/met11010096

Received: 7 December 2020 Accepted: 31 December 2020 Published: 6 January 2021

Publisher's Note: MDPI stays neutral with regard to jurisdictional clai$\mathrm{ms}$ in published maps and institutional affiliations.

Copyright: (C) 2021 by the authors. Licensee MDPI, Basel, Switzerland. This article is an open access article distributed under the terms and conditions of the Creative Commons Attribution (CC BY) license (https:// creativecommons.org/licenses/by/ $4.0 /)$.
State Key Laboratory of Rolling and Automation, Northeastern University, Shenyang 110819, China; zyliu@mail.neu.edu.cn (Z.L.); wanggd@mail.neu.edu.cn (G.W.)

* Correspondence: tangshuai@ral.neu.edu.cn (S.T.); lanhf@ral.neu.edu.cn (H.L.); Tel.: +86-24-8368-6419 (S.T.)

\begin{abstract}
The microstructural evolution and properties for varied austempering routes are investigated in a cold-rolled bainitic steel. Special attention is given to the effect of retained austenite (RA) in terms of its fraction, carbon concentration, and morphology resulting from different austempering routes on mechanical properties and stretch flangeability. Bimodal sized bainitic laths are provided, and the carbon concentration of RA maintains the highest value through the two-step austempering. Total elongation (TEL) is remarkably enhanced for the two-step austempering, deviating from the exponential relationship between tensile strength (TS) and TEL as maintained by the one-step austempering. Considering the two plateaus of the strain-hardening exponent, it is considered that the hierarchical stability of RA is provided by the two-step austempering, leading to the postponed necking point so as to improve the uniform elongation. Two-step austempering could provide more complete bainitic transformation as well as more stable film-like RA, supplying a promising way to improve the combination of strength, ductility, and stretch flangeability.
\end{abstract}

Keywords: bainitic steel; two-step austempering; retained austenite; strain hardening; stretch flangeability

\section{Introduction}

The application of high-strength steel is one of the most effective ways to reduce car body weight while ensuring the required safety. The multiphased steels with a combination of varied phases, such as ferrite, martensite/bainite, and retained austenite (RA) are developed to satisfy the demand of structural parts. Among them, bainitic steels are attractive because of their good combination of strength and ductility. It is well accepted that the bainitic lath size, which is determined by the transformation temperature, strongly affects the strength. For instance, Sandvik et al. [1] found that strength can be obviously increased by refining the bainitic lath size through decreasing the austempering temperature. Bhadeshia et al. [2,3] developed an ultra-high strength bainitic steel with an excellent balance of strength and ductility (tensile strength higher than $2000 \mathrm{MPa}$ and total elongation higher than $20 \%$ ) by refining the bainitic lath to tens of nanometers through a low-temperature austempering treatment. Furthermore, remarkable ductility is provided due to a considerable fraction of RA by means of the transformation of metastable austenite into martensite, i.e., the transformation-induced plasticity (TRIP) effect.

In addition, it is considered that the hardness difference between the soft and hard phase can be avoided in bainitic steels, so that ensures the excellent combination of strength and local formability [4-6] through retarding the strain localization. It is reported that a certain fraction of RA with relatively high stability is important for the improvement of the stretch flangeability, because it can suppress the strain-induced transformation in the punched hole-surface layer before hole expansion and consequently improve the localized ductility on hole-expanding through the superior TRIP effect [7]. Therefore, it is crucial to maintain a good balance of strength, ductility, and local formability by optimizing the bainitic lath size as well as the fraction and stability of RA. 
The fraction of RA can be increased through increasing the austempering temperature. However, this is at the expense of the strength decreasing [8]. Hase et al. [9] obtained a bimodal size distributed bainitic microstructure through a two-step austempering in which blocks of austenite were refined and the RA was further stabilized, achieving a much higher combination of strength, ductility, and fracture toughness than the one-step counterparts. Xie et al. [10] reported that a two-step austempering could further stabilize the RA, leading to a significant increase in ductility as well as a strength-ductility balance.

In this study, we have studied the effect of austempering treatment in terms of temperature and holding time on the microstructure, mechanical properties, and stretch flangeability. Comparison of the fraction of RA and its stability and properties was made between one-step and two-step austempering treatment. The role of RA on work-hardening behavior, failure behavior during hole expansion, and on a combination of strength, ductility, and stretch flangeability was elucidated.

\section{Materials and Methods}

The chemical composition of the experimental steel is listed in Table 1 . The steel was melted under vacuum in an induction furnace (North Electric Furnace Factory, Jinzhou, China) and cast as ingots. The addition of relatively high $\mathrm{Si}$ is expected to suppress the precipitation of cementite during bainite transformation, with an indirect effect on the stabilization of austenite through the carbon enrichment of austenite as a result of the fact that Si has very low solubility in cementite. It should be noted that Si can be partially or completely replaced by $\mathrm{Al}$ and/or P considering their similar effect [11-14]. Nb was added to enhance grain refinement.

Table 1. Chemical composition of experimental steel (wt \%).

\begin{tabular}{cccccc}
\hline $\mathbf{C}$ & $\mathbf{S i}$ & $\mathbf{M n}$ & $\mathbf{N b}$ & $\mathbf{P}$ & $\mathbf{S}$ \\
\hline 0.20 & 1.40 & 1.70 & 0.045 & 0.020 & 0.045 \\
\hline
\end{tabular}

Aluminum is well known for its ability to hinder the carbide precipitation similar to silicon; besides, it increases the stability of retained austenite [8]. In addition, the main feature of using aluminum is that it represents much better surface quality compared to silicon.

The ingot was hot forged into blocks with a thickness of $50 \mathrm{~mm}$. After austenitization at $1200{ }^{\circ} \mathrm{C}$ for $2 \mathrm{~h}$, the block was hot rolled to plate of thickness $\approx 4.5 \mathrm{~mm}$ via 7 passes and the finish rolling temperature was about $900{ }^{\circ} \mathrm{C}$, which was followed by accelerated cooling to $600{ }^{\circ} \mathrm{C}$ with subsequent air cooling to room temperature.

The hot-rolled plates were further cold rolled to $1.2 \mathrm{~mm}$ with a total rolling reduction of $73.3 \%$. The dilatometric samples were machined from the cold-rolled plate $(4 \mathrm{~mm} \times 10 \mathrm{~mm})$ and were performed on a DIL 805 dilatometer (Bähr, Germany) to investigate the microstructural evolution during austempering. The thermocouples were spot-welded at the center as well as at the end of the sample to monitor the temperature homogeneity. Austenization at $950{ }^{\circ} \mathrm{C}$ for $180 \mathrm{~s}$ was adopted. The Ms temperature under this condition is $364{ }^{\circ} \mathrm{C}$. In order to investigate the influence of austempering parameters on properties, a continuous annealing experiment was carried out using a CAS300-II continuous annealing simulator (RAL, Shenyang, China). The austempering is carried out at $370^{\circ} \mathrm{C}$ and $400{ }^{\circ} \mathrm{C}$ for $50-500 \mathrm{~s}$. In addition, a two-step austempering is adopted, where the austempering temperature is $370{ }^{\circ} \mathrm{C}$ and $400{ }^{\circ} \mathrm{C}$ for the first and second step, respectively. The schematic diagrams of the detailed experimental parameters are shown in Figure 1. 


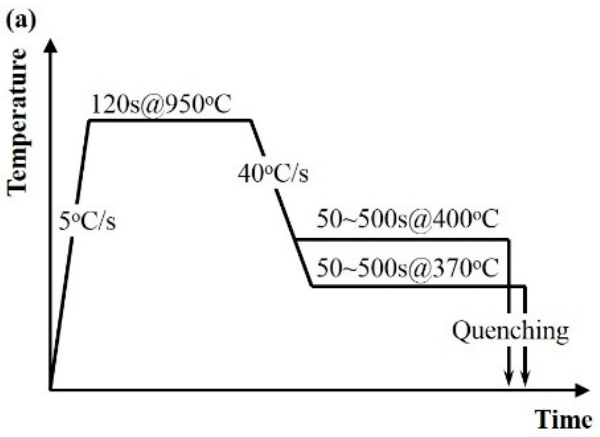

(a)

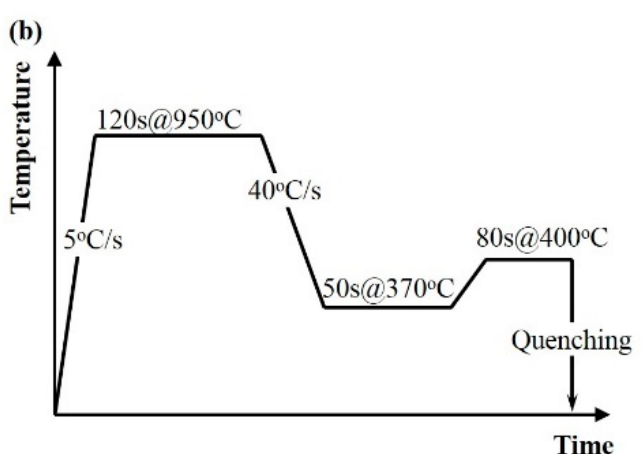

(b)

Figure 1. Schematic diagrams for continuous annealing experiments, (a) one-step, (b) two-step.

To examine the microstructure, specimens were mechanically polished and etched with $2 \%$ nital solution and observed using Zesis Ultra 55 field emission gun scanning electron microscope (FEG-SEM, Carl Zeiss AG, Jena, Germany). For TEM studies, samples were cut into $500 \mu \mathrm{m}$ thick slices and mechanically ground to a thickness of $50 \mu \mathrm{m}$. Disks of $3 \mathrm{~mm}$ diameter were punched and electropolished in Struer's Tenupol twin-jet polisher (Struers, Willich, Germany) using a solution of 93\% alcoholic solution and 7\% perchloric acid. The foils were observed in FEI TecnaiG ${ }^{2}$ F20 transmission electron microscope (FEI, OR, USA) at an operating voltage of $200 \mathrm{kV}$. The electron backscattered diffraction (EBSD) studies were carried out in FEG-SEM for automatic orientation mapping with a $0.07 \mu \mathrm{m}$ step size. EBSD data were processed by HKL CHANNEL 5 software (Oxford company, Abingdon-on-Thames, UK). Quantitative X-ray diffraction was carried out to determine the volume fraction of RA $\left(V_{\gamma}\right)$ and its carbon concentration $\left(C_{\gamma}\right)$. The samples were electropolished using the aforementioned method and were scanned with a Bruker D8 $X$-ray diffractometer (XRD, Bruker AXS Inc., USA) at a step size of $0.02^{\circ}$ and a count time of $1.2 \mathrm{~s}$ per step using $\mathrm{Co}-\mathrm{K} \alpha$ radiation. The (200) and (220) diffraction peaks of austenite and (200) and (211) diffraction peaks of ferrite were selected to calculate the $V_{\gamma}$ [15]. The multiple diffraction peaks were combined to minimize the influence of preferred orientation. The equation $a_{\gamma}=3.556+0.0453 C_{\gamma}$ was used to calculate $C_{\gamma}$ (wt \%) in RA [16], where $a_{\gamma}(\AA)$ is the lattice parameter of austenite.

Tensile tests were carried out using standard rectangular specimens with a gauge length of $30 \mathrm{~mm}$ and a crosshead speed of $1 \mathrm{~mm} / \mathrm{min}$ using a SANS 5105 testing machine (SANS, Shenzhen, China) with a $100 \mathrm{kN}$ load cell. In each condition, three specimens were tested to obtain an average of mechanical properties. A hole expansion experiment was performed in a universal testing machine. A conical punch of $10 \mathrm{~mm}\left(d_{0}\right)$ diameter and angle of $60^{\circ}$ was used for these tests. To better investigated the relationship between mechanical properties and local formability, the hole was processed by using a wire electrical discharge cutting machine (BUAA, Beijing, China) to minimize the accumulated shearing damage as well as the defect such as micro-cracks caused by the conventional punching method. A speed of $3 \mathrm{~mm} / \mathrm{min}$ with a blank holder force of $50 \mathrm{KN}$ was used in the experiment. The hole expansion rate (HER) was calculated by the equation $H E R=\left(d-d_{0}\right) / d_{0} \times 100 \%$, where $d$ and $d_{0}$ are the fractured hole diameter and the initial hole diameter, respectively.

\section{Results and Discussion}

\subsection{Microstructural Characterization}

Figure 2 shows the SEM micrographs of specimens austempered at $370{ }^{\circ} \mathrm{C}$ and $400{ }^{\circ} \mathrm{C}$ for 50-500 s. For both austempering temperature, the microstructure mainly displays lath morphology. Blocky martensite islands (marked with white arrows) are observed for the holding time of $50 \mathrm{~s}$ (Figure 2a,e), which were formed from untransformed austenite during subsequent cooling after austempering. When the austempering time increases to $180 \mathrm{~s}$, 
the amount and size of the blocky martensite is obviously decreased but still can be found, especially for $400{ }^{\circ} \mathrm{C}$ austempering (shown with white arrows in Figure 2f). The microstructure is similar for $250 \mathrm{~s}$ and $500 \mathrm{~s}$ austempering, implying that the bainite transformation is completed up to $250 \mathrm{~s}$. In addition, the width of the bainitic lath as well as the interlath film-like retained austenite/martensite (RA/M) seems wider for $400{ }^{\circ} \mathrm{C}$ austempering. For the two-step sample (Figure 2i), one can see a refined microstructure with lath morphology, similar with that in Figure 2e. In addition, a coarser lath microstructure with wider $\mathrm{RA} / \mathrm{M}$ instead of large blocky martensite islands is found, which is considered to result from the bainitic transformation at $400{ }^{\circ} \mathrm{C}$.

Figure 3 shows the image quality map with RA distribution measured by EBSD for $400{ }^{\circ} \mathrm{C}$ austempering with a holding time of $50 \mathrm{~s}$ and $250 \mathrm{~s}$ and two-step austempering. It is found that for the holding time of $50 \mathrm{~s}$, the detected amount of RA is low with blocky morphology (Figure 3a). As the holding time increases to $250 \mathrm{~s}$ (Figure 3b), the amount of RA is remarkably increased, and the RA particles tend to display a rod-like shape. For the two-step austempering (Figure 3c), the morphology of RA is alike with that in Figure $3 b$, but it seems that more thin film-like RA exists in the microstructure.
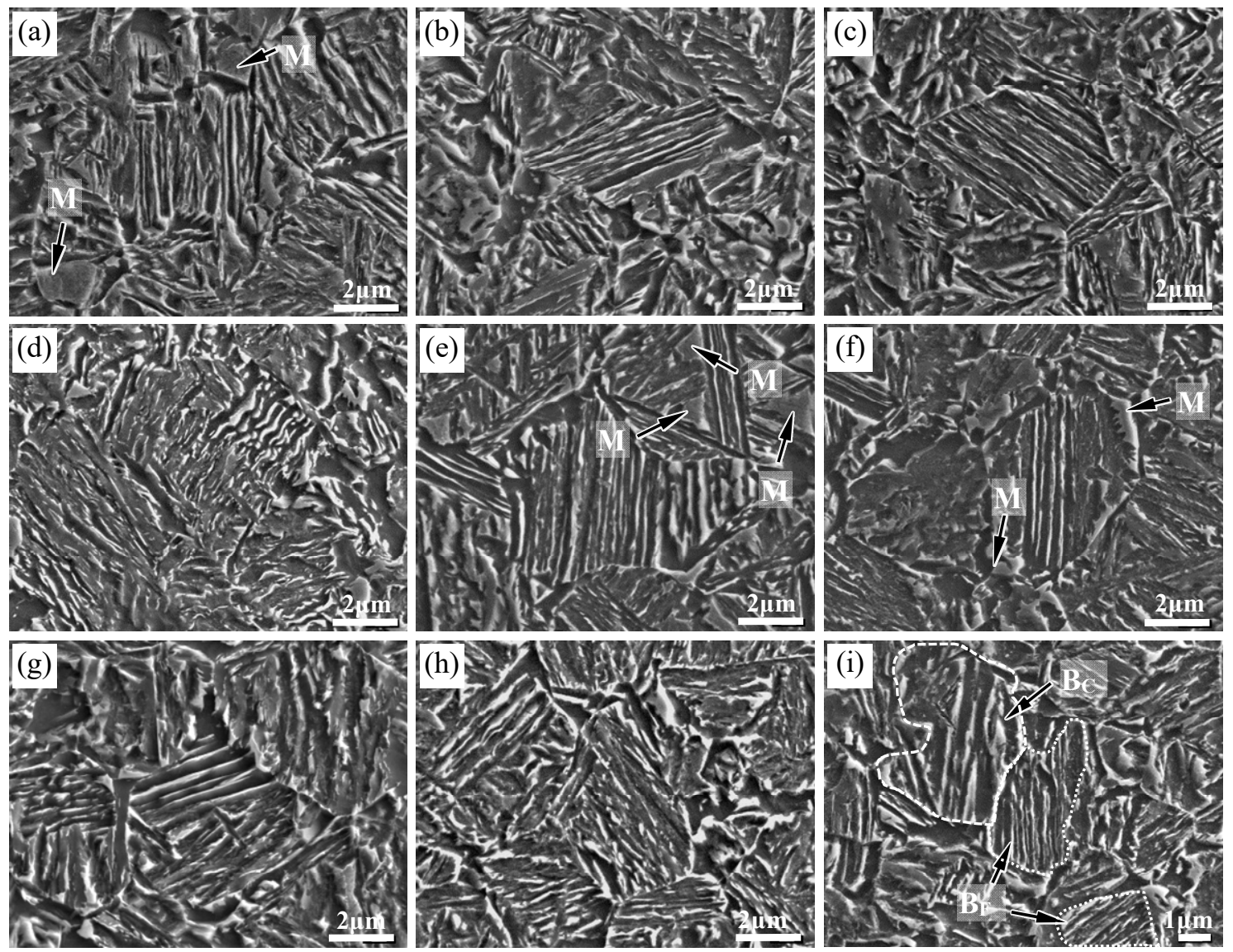

Figure 2. Microstructures for different austempering temperature and time. (a-h) One-step austempering, (a) $50 \mathrm{~s} @ 370{ }^{\circ} \mathrm{C}$, (b) $180 \mathrm{~s} @ 370{ }^{\circ} \mathrm{C}$, (c) $250 \mathrm{~s} @ 370{ }^{\circ} \mathrm{C}$, (d) $500 \mathrm{~s} @ 370{ }^{\circ} \mathrm{C}$, (e) $50 \mathrm{~s} @ 400{ }^{\circ} \mathrm{C}$, (f) $180 \mathrm{~s} @ 400{ }^{\circ} \mathrm{C},(\mathrm{g}) 250 \mathrm{~s} @ 400{ }^{\circ} \mathrm{C},(\mathbf{h}) 500 \mathrm{~s} @$ $400{ }^{\circ} \mathrm{C}$, (i) two-step austempering $50 \mathrm{~s} @ 370{ }^{\circ} \mathrm{C}+80 \mathrm{~s} @ 400^{\circ} \mathrm{C}, \mathrm{M}$-martensite, $\mathrm{B}_{\mathrm{C}}$-Coarser Bainite, $\mathrm{B}_{\mathrm{F}}$-Finer Bainite. 

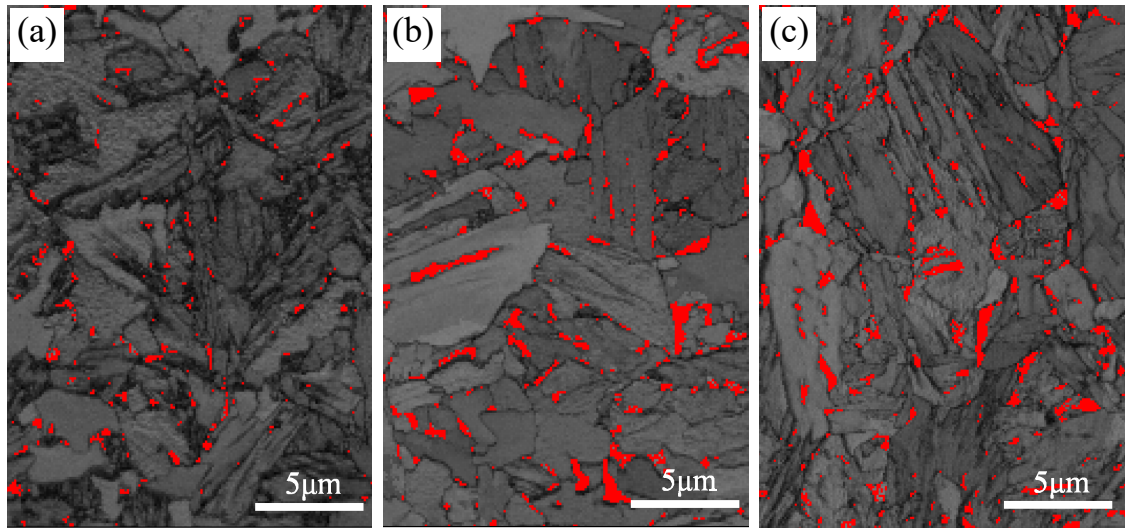

Figure 3. Image quality map with RA distribution measured by electron backscattered diffraction (EBSD) under different austempering parameters, (a) one-step $50 \mathrm{~s} @ 400{ }^{\circ} \mathrm{C}$, (b) one-step $250 \mathrm{~s} @$ $400{ }^{\circ} \mathrm{C}$, (c) two-step $50 \mathrm{~s} @ 370{ }^{\circ} \mathrm{C}+80 \mathrm{~s} @ 400{ }^{\circ} \mathrm{C}$, where the red color represents the RA.

Figure 4 shows the TEM morphology of blocky martensite and film-like RA for $50 \mathrm{~s}$ and $250 \mathrm{~s}$ austempering, respectively. In Figure $4 \mathrm{a}$, blocky martensite is presented, in which twinned martensite is found, indicating the high carbon concentration. As is shown in Figure 2a,e the transformation at the holding time of $50 \mathrm{~s}$ is not completed. The untransformed austenite may transform to martensite due to its insufficient stabilization, and only a few fractions of austenite would be retained at room temperature. With the completion of transformation at a longer holding time, the RA with a film-like shape mainly lies between bainitic laths and blocks, as shown in Figure $4 \mathrm{~b}$.
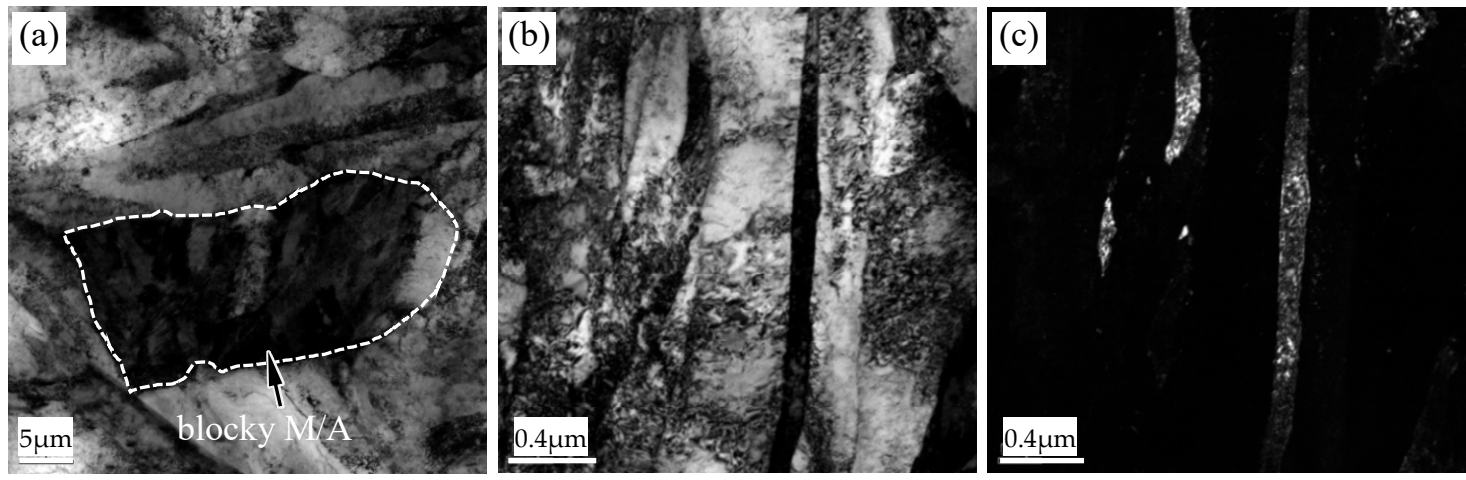

Figure 4. The TEM morphology of specimens austempered at $400{ }^{\circ} \mathrm{C}$ for different times, (a) $50 \mathrm{~s}$, (b) $250 \mathrm{~s}$ (bright field of RA), (c) $250 \mathrm{~s}$ (dark field of RA).

Figure 5 shows $V_{\gamma}$ and $C_{\gamma}$ with different austempering parameters. Both $V_{\gamma}$ and $C_{\gamma}$ are lower for $370{ }^{\circ} \mathrm{C}$ than for $400{ }^{\circ} \mathrm{C}$ austempering. It is found that $V_{\gamma}$ increases rapidly from 50 to $180 \mathrm{~s}$, with the same trend of EBSD measurement (Figure 3a,b), and then it increases slightly and remains stable with the increasing of holding time after $180 \mathrm{~s}$. $C_{\gamma}$ also increases sharply from 50 to $180 \mathrm{~s}$, resulting from the proceeding of bainitic transformation. Then, it increases gradually with the increasing of holding time, indicating the continuous carbon partitioning during the austempering. The average $V_{\gamma}$ and $C_{\gamma}$ for the two-step austempering is $12.2 \%$ and $1.39 \mathrm{wt} \%$, respectively. The $C_{\gamma}$ is the highest among these specimens. 


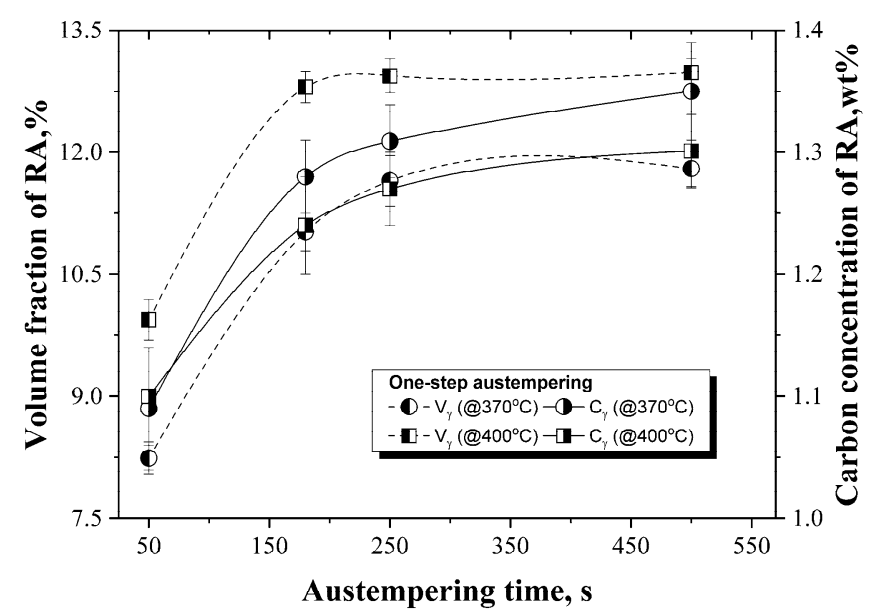

Figure 5. Volume fraction and carbon concentration of retained austenite (RA).

\subsection{Analysis of Microstructural Evolution}

For the two-step austempering process, the microstructure morphology as well as features (fraction, stability, etc.) of RA are determined by the combination of the two steps. While austempering at a lower temperature, i.e., $370{ }^{\circ} \mathrm{C}$ for $50 \mathrm{~s}$ (first-step) in this study, finer bainitic laths with higher defect density would be formed. Considering the relatively short holding time, austenite is partially retained at the end of the first-step austempering. In the following austempering at $400{ }^{\circ} \mathrm{C}$ (second-step), untransformed austenite further transforms into bainite with a larger lath size, and a higher proportion of austenite may be retained in this case. The schematic diagram of the microstructure evolution is shown in Figure 6. Considering the two-step bainitic transformation as well as the carbon partitioning, it is probable that the two-level stability of RA may be provided through the two-step austempering. It may include the more stable austenite obtained at $370{ }^{\circ} \mathrm{C}$ austempering, which is further stabilized by subsequent $400{ }^{\circ} \mathrm{C}$ austempering and the less stable austenite formed at $400{ }^{\circ} \mathrm{C}$ austempering.

Consequently, three items can be achieved for the microstructural optimization. Firstly, bainite transformation proceeds more completely compared to the one-step $400{ }^{\circ} \mathrm{C}$ austempering, replacing blocky M/A constituents with film-like RA. Secondly, the untransformed austenite at the end of the second-step austempering is further enriched in carbon, leading to a higher carbon concentration in the final RA compared to the $370{ }^{\circ} \mathrm{C}$ austempering for 50 and $180 \mathrm{~s}$. The above two features contribute to the improvement of ductility and stretch flangeability. Thirdly, a large quantity of fine lath bainite is formed at the first step, maintaining high strength. Therefore, it is indicated that the two-step austempering process provides a good way to balance the strength, ductility, and stretch flangeability.

It is proposed that the bainite transformation ceases once the carbon concentration of austenite reaches $T_{0}$ line, where the fcc (face-centered cubic) and bcc (body-centered cubic) phase with identical composition have the same free energy [17]. Figure 7 shows the $T_{0}$ and $P E$ (para-equilibrium) line calculated by Thermo-calc software (2019a version) based on the TCFE 9 database with accompanied with measured $C_{\gamma}$. One can see that the actual $C_{\gamma}$ is close to the $T_{0}$ line for the holding time of $50 \mathrm{~s}$, and it exceeds the $T_{0}$ line as the austempering time increases. Moreover, $C_{\gamma}$ for the two-step austempering is further increased. This is attributed to the fact that carbon partitions from post-transformed bainite to austenite. In particular, carbon enrichment further occurs from lower-temperature bainitic ferrite into neighboring austenite at a higher austempering temperature, because part of the carbon atoms is usually trapped in bainitic laths with high dislocation density [18-20]. However, $C_{\gamma}$ is still far from the line of $P E$, which is a local equilibrium for carbon, but there is no diffusion of iron and substitutional elements. 


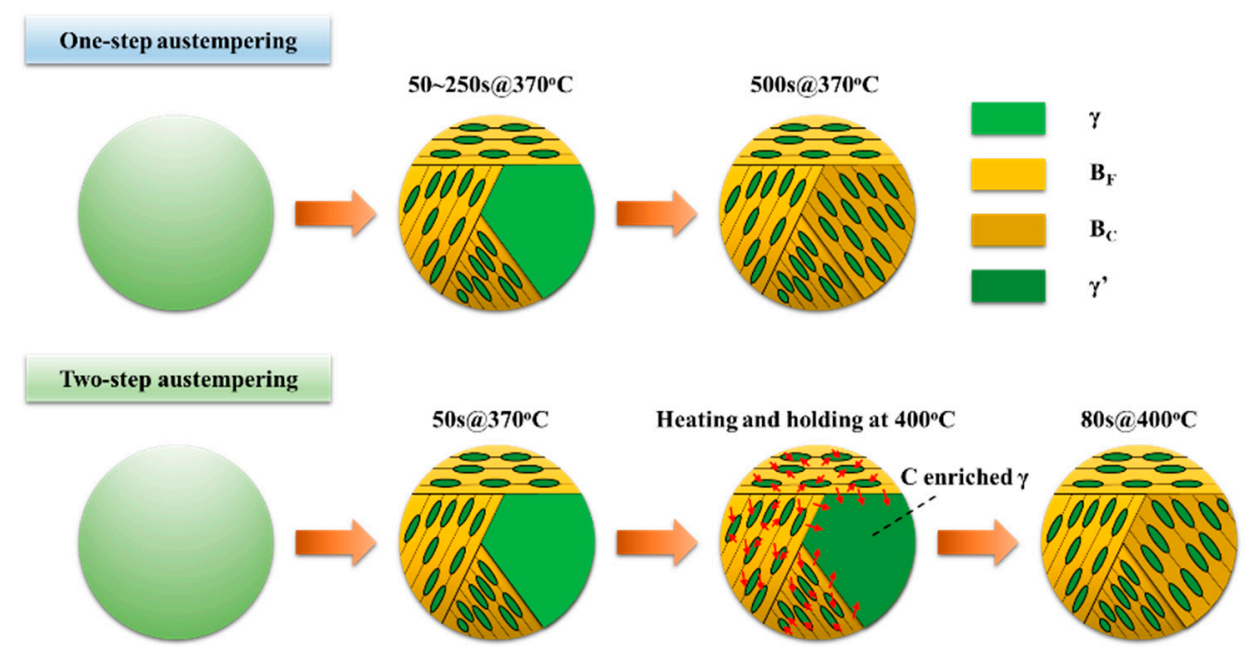

Figure 6. Schematic diagrams of microstructure evolution with two-step bainite transformation.

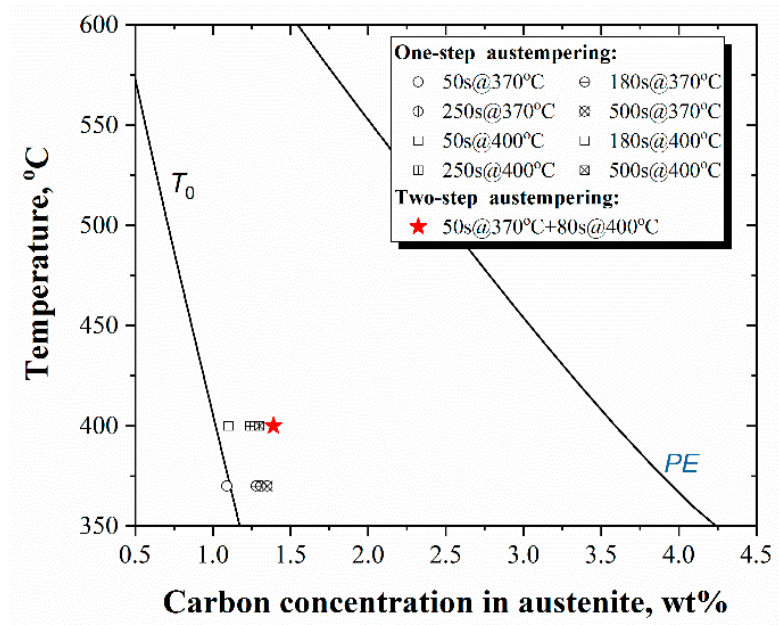

Figure 7. Comparison of measured $C_{\gamma}$ with $T_{0}$ and $P E$ composition, calculated by Thermo-calc software (2019a version) based on the TCFE 9 database.

\subsection{Mechanical Properties}

Figure 8a shows the effects of austempering temperature and holding time on mechanical properties. For both austempering temperature, tensile strength (TS) and yield strength (YS) decrease with the increasing of austempering time, and TS slightly decreases when the holding time is longer than $250 \mathrm{~s}$. Correspondingly, the total elongation (TEL) increases as the austempering time is prolonged. The higher TS as well as the lower TEL at the early stage of austempering is considered to be caused by the blocky martensite. From Figure 8b, one can see that $T E L$ decreases continuously with the increase of $T S$, maintaining an exponential trend between TEL and TS for the one-step austempering process, as reported in lots of studies in the literature $[8,21,22]$. However, it is interesting to note that TEL is remarkably enhanced for the two-step austempering, improving the strength-ductility balance in this case. 


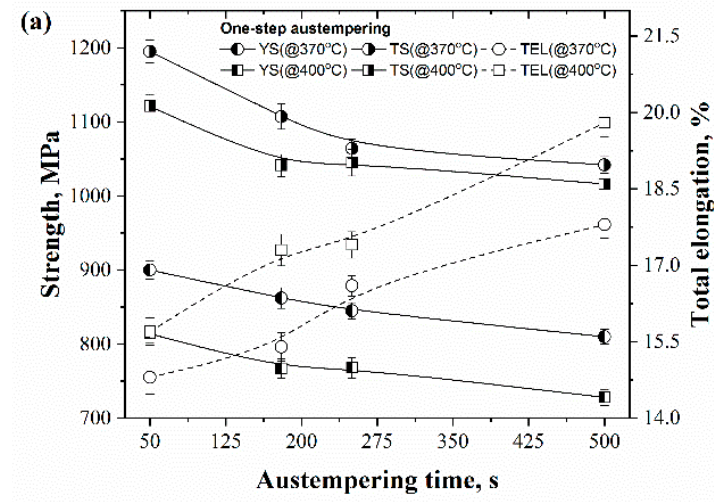

(a)

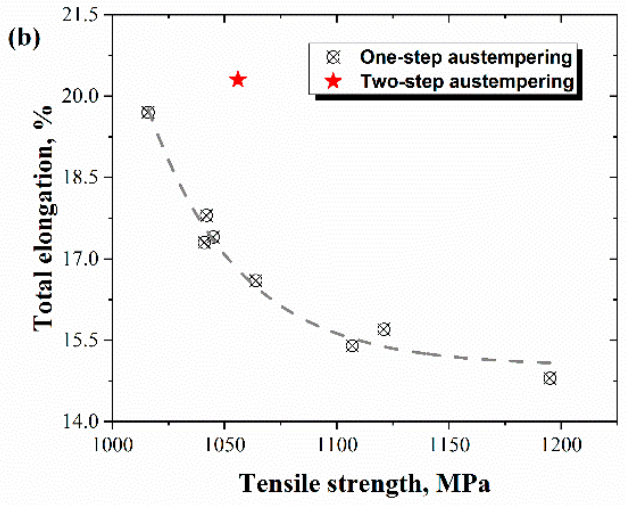

(b)

Figure 8. Mechanical properties under different austempering temperature and holding time (a) and relationship between TEL and TS (b).

The following formulas were used to calculate the true stress-true strain data from the engineering data obtained through tensile testing.

$$
\begin{gathered}
\varepsilon_{\text {true }}=\ln (1+e) \\
\sigma_{\text {true }}=\sigma_{\text {eng }}(1+e)
\end{gathered}
$$

where $\varepsilon_{\text {true }}$ is true strain, $\sigma_{\text {true }}$ is true stress, $e$ is engineering strain, and $\sigma_{\text {eng }}$ is engineering stress, and the strain hardening exponent $n$ is calculated as:

$$
n=\frac{d\left(\ln \sigma_{\text {true }}\right)}{d\left(\ln \varepsilon_{\text {true }}\right)}
$$

Figure 9 shows the strain-hardening exponent versus true strain for three austempering processes. The strain-hardening exponent of three processes decreases quickly at first and then decreases with a slower rate, forming the first plateau. In the following, it decreases quickly again and then increases with a slow rate, forming the second plateau. It seems that the length of the second plateau for $370{ }^{\circ} \mathrm{C}$ austempering is shorter compared to the other two processes, which may result from the lower fraction of RA considering that the carbon concentration is close to that for $400{ }^{\circ} \mathrm{C}$ austempering.

It is interesting to note that the length of the first plateau for the two-step austempering is obviously longer than its counterparts. It is probably because most RA, on the one hand, are in a film-like shape; and on the other hand, they possess a higher carbon concentration due to adequate partitioning in the second-step austempering, both of which lead to high stability of RA. In this case, the RA could transform more gradually to martensite during straining $[23,24]$, leading to a longer first plateau. Especially, the longer first plateaus contributed by RA allow the necking point to be postponed, improving the uniform elongation. Considering the corresponding relationship between the plateaus and RA, the existence of the two-level stability of RA provided through the two-step austempering is confirmed. 


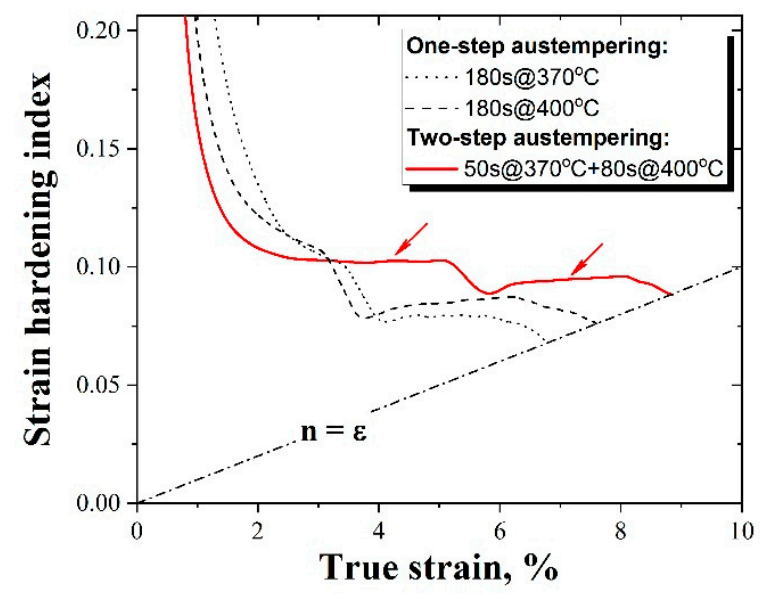

Figure 9. Strain-hardening exponent versus true strain.

\subsection{Stretch Flangeability}

Figure 10a shows the HER under varied austempering temperature and time. The HER is generally higher for $400{ }^{\circ} \mathrm{C}$ than for $370{ }^{\circ} \mathrm{C}$ austempering. With the increasing of holding time, $H E R$ increases gradually for $370{ }^{\circ} \mathrm{C}$ austempering, but it remains stable for the holding time of 180 to $500 \mathrm{~s}$ for $400{ }^{\circ} \mathrm{C}$ austempering. The $H E R$ value is $54 \pm 3 \%$ for the two-step austempering. It is reported that there is a strong correlation between HER and TS where $H E R$ decreases with the increasing of TS up to approximately $700 \mathrm{MPa}$, but it is insensitive to the change of TS for TS beyond $700 \mathrm{MPa}$ [25]. Figure $10 \mathrm{~b}$ shows the experimental data in this study along with data from the literature [18]. One can see that the data in this study bring a deviation from the trend in the strength range from 1000 to $1200 \mathrm{MPa}$. Similarly, there is also data scattering for dual phase (DP) steel in this figure. The reason is that factors that less directly affect the TS, such as the morphology of martensite [26] and hardness ratio of ferrite and martensite $[6,27]$, also play a significant role in the HER value for DP steel. It is believed that the deviation in the TS-HER relationship for the studied steel results from the optimal combination of bainite matrix and retained austenite.

(a)

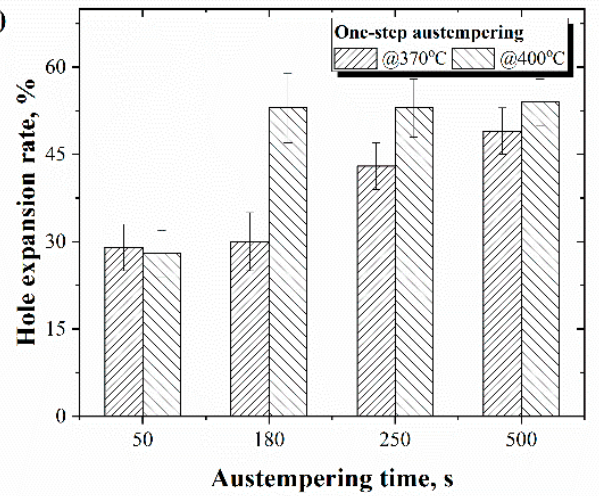

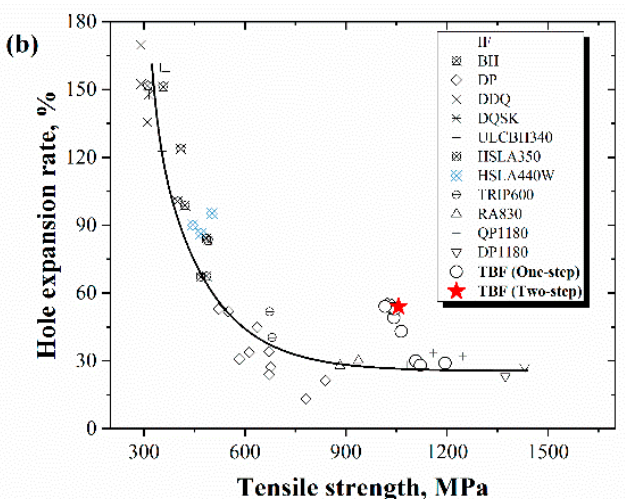

Figure 10. (a) Hole expansion rate (HER) under different austempering temperature and time, and (b) HERs versus tensile strength (TS) for varied steel grades [18] with data in this study.

In our previous study [28], there is a linear relationship between the yield ratio $(Y R)$ and HER value, in which ferrite exists in the microstructure. However, $Y R$ in this study is similar, ranging from 0.74 to 0.76 , so it is ruled out as a possible factor that may correlate with HER. In this respect, one can say that the influence of $Y R$ on HER is much more notable for a mixed microstructural constituent than a single microstructural constituent.

The TRIP effect is reported to prevent strain localization, and martensite transformation occurring at low strains tends to decrease the HER [29]. During the hole expansion test, a higher HER would be obtained through a steady and continuous transformation 
of RA to martensite throughout the test. Thus, the stability of RA plays a key role in stretch flangeability. It is known that stability of RA is determined by both chemical and mechanical stability [30-34]. The carbon concentration in the RA is responsible for its chemical stability [34,35], whereas mechanical stability is determined by other factors such as size [31], morphology [34-36], and the surrounding microstructure of RA [30].

Figure 11 shows SEM cross-sectional micrographs nearby the main crack in hole expansion specimens austempered at $400{ }^{\circ} \mathrm{C}$ for $50 \mathrm{~s}$ and $180 \mathrm{~s}$. In Figure 11a,b, tiny cracks are observed among the fine bainite region with film-like RA/M (some RA may transform to martensite due to the TRIP effect during hole expanding). Crack propagation may be inhibited by TRIP effect of the film-like RA as well as by the tough film-like RA itself, which is in accordance with the research of Sugimoto et al. [4,30]. However, a large quantity of voids appears in the vicinity of blocky martensite (shown with white arrows). It is indicated that the strain incompatibility between the matrix and hard blocky martensite is the dominant cracking mechanism during hole expanding in this case. Strain partitioning to the softer matrix occurs during deformation, potentially inducing more damage to the matrix close to the hard phase, resulting in the nucleation and growth of voids in these regions [37]. Yang et al. [38] also reported that large blocky RA/M boosts the crack nucleation. The blocky martensite originated from two parts. One part is the intrinsic, which is formed during the cooling process after austempering treatment. The other part comes from the large blocky RA through the TRIP effect in the early stage of local forming deformation. This would lower the HER by early failure in the vicinity of blocky martensite through void or crack formation. Thus, tendering more complete bainitic transformation as well as more film-like RA through two-step austempering would help improve the stretch flangeability.

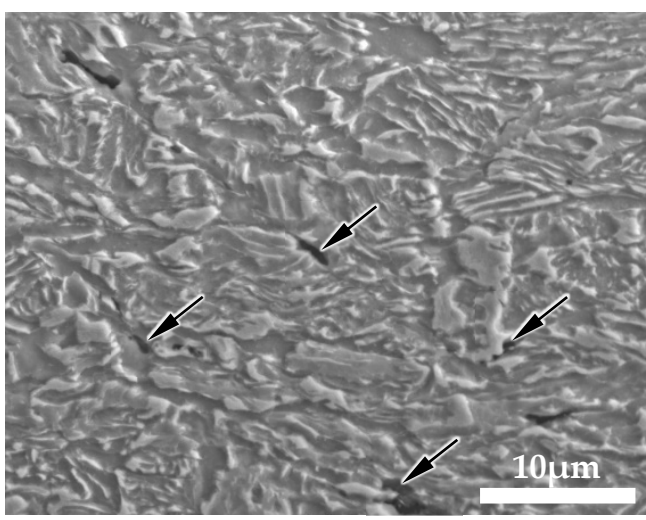

(a)

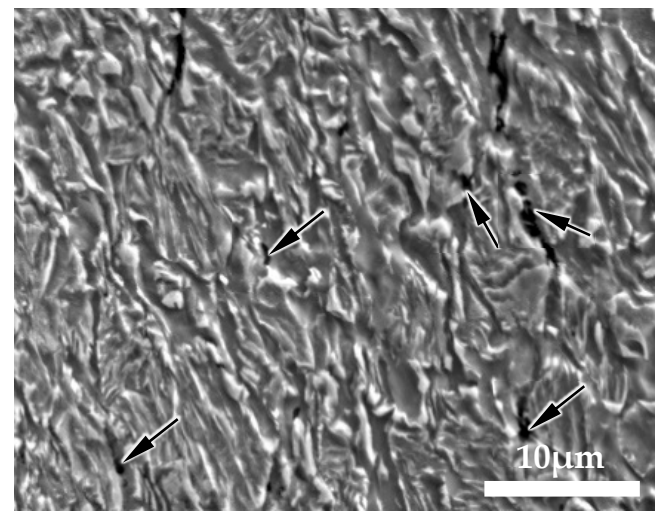

(b)

Figure 11. SEM morphology of the cross-sectional area near the main crack after hole expansion, (a) $400{ }^{\circ} \mathrm{C}$ austempering for $50 \mathrm{~s}$, (b) $400{ }^{\circ} \mathrm{C}$ austempering for $180 \mathrm{~s}$.

\section{Conclusions}

In this study, the microstructural evolution of the TRIP-aided bainitic steel under different austempering routes was investigated. The effect of the microstructure (bainite and RA) on the mechanical properties as well as on stretch flangeability was elucidated. The main conclusions from this work are as follows:

(1) With the increasing of austempering temperature, the width of both bainitic lath and interlath film-like RA/M becomes wider. The bimodal bainitic lath size is provided through the two-step austempering. Both $V_{\gamma}$ and $C_{\gamma}$ are lower for $370{ }^{\circ} \mathrm{C}$ than for $400{ }^{\circ} \mathrm{C}$ austempering. The $C_{\gamma}$ for the two-step austempering maintains the highest value, which is attributed to the fact that carbon enrichment further occurs from lower-temperature bainitic ferrite into neighbored austenite at higher austempering temperature in the second step of austempering. 
(2) TS and YS decrease with the increasing of austempering time, and TS slightly decreases when the holding time is longer than $250 \mathrm{~s}$. TEL increases as the austempering time is prolonged. The higher TS as well as lower TEL at the early stage of austempering is caused by the blocky martensite. In contrast, TEL is remarkably enhanced for the two-step austempering, deviating from the exponential relationship between TS and TEL as maintained by the one-step austempering.

(3) In light of the two plateaus of the strain-hardening exponent, it is considered that the two-level stability of RA exists, which is provided by the two-step austempering. The two longer plateaus allow the necking point to be postponed, improving the uniform elongation.

(4) Strain incompatibility between the matrix and hard blocky martensite is the dominant cracking mechanism during hole expanding. Tendering more complete bainitic transformation as well as more film-like RA would help improve the stretch flangeability. The two-step austempering may be a promising way to ensure a good combination of strength, ductility, and stretch flangeability.

Author Contributions: Conceptualization, S.T. and H.L.; methodology, S.T.; experiment, S.T. and H.L.; formal analysis, S.T. and H.L.; investigation, S.T. and H.L.; writing-original draft preparation, S.T.; writing—review and editing, H.L. supervision, Z.L.; project administration, G.W. All authors have read and agreed to the published version of the manuscript.

Funding: This study was supported by the National Natural Science Foundation of China (Grant Nos. 51774083 and 51774082), the Fundamental Research Funds for the Central Universities (Grant No. N2007011), 111 Project (Grant No. B20029), and National Key Research and Development Program (Grant No. 2017YFB0304402).

Institutional Review Board Statement: Not applicable.

Informed Consent Statement: Not applicable.

Data Availability Statement: The data presented in this study are available on request from the corresponding author.

Conflicts of Interest: The authors declare no conflict of interest.

\section{References}

1. Sandvik, B.P.J.; Nevalainen, H.P. Structure-property relationship in commercial low-alloy bainitic-austenitic steel with high strength, ductility and toughness. Met. Technol. 1981, 15, 213-220. [CrossRef]

2. Caballero, F.G.; Bhadeshia, H.K.D.H. Very strong bainite. Curr. Opin. Solid State Mater. Sci. 2004, 8, 251-257. [CrossRef]

3. Yokota, T.; García Mateo, C.; Bhadeshia, H.K.D.H. Formation of nanostructured steels by phase transformation. Scripta Mater. 2004, 51, 767-770. [CrossRef]

4. Sugimoto, K.; Sakaguchi, J.; Iida, T.; Kashima, T. Stretch-flangeability of a high-strength TRIP type bainitic sheet steel. ISIJ Int. 2000, 40, 920-926. [CrossRef]

5. Hausmann, K.; Krizan, D.; Spiradek-Hahn, K.; Pichler, A.; Werner, E. The influence of $\mathrm{Nb}$ on transformation behavior and mechanical properties of TRIP-assisted bainitic-ferritic sheet steels. Mater. Sci. Eng. A 2013, 588, 142-150. [CrossRef]

6. Hasegawa, K.; Kawamura, K.; Urabe, T.; Hosoya, Y. Effects of microstructure on stretch-flange-formability of 980 MPa grade cold-rolled ultra high strength steel sheets. ISIJ Int. 2004, 44, 603-609. [CrossRef]

7. Sugimoto, K.; Iida, T.; Sakaguchi, J.; Kashima, T. Retained austenite characteristics and tensile properties in a TRIP type bainitic sheet steel. ISIJ Int. 2000, 40, 902-908. [CrossRef]

8. Zhao, J.; Lv, B.; Zhang, F.; Yang, Z.; Qian, L.; Chen, C.; Long, X. Effects of austempering temperature on bainitic microstructure and mechanical properties of a high-C high-Si steel. Mater. Sci. Eng. A 2019, 742, 179-189. [CrossRef]

9. Hase, K.; Garcia-Mateo, C.; Bhadeshia, H.K.D.H. Bimodal size-distribution of bainite plates. Mater. Sci. Eng. A 2006, 438-440, 145-148. [CrossRef]

10. Xie, Z.J.; Ren, Y.Q.; Zhou, W.H.; Yang, J.R.; Shang, C.J.; Misra, R.D.K. Stability of retained austenite in multi-phase microstructure during austempering and its effect on the ductility of a low carbon steel. Mater. Sci. Eng. A 2014, 603, 69-75. [CrossRef]

11. Jacques, P.J.; Girault, E.; Mertens, A.; Verlinden, B.; van Humbeeck, J.; Delannay, F. The Developments of cold-rolled TRIP-assisted multiphase steels. Al-alloyed TRIP-assisted multiphase steels. ISIJ Int. 2001, 41, 1068-1074. [CrossRef]

12. De Meyer, M.; Vanderschueren, D.; De Cooman, B.C. The influence of the substitution of Si by Al on the properties of cold rolled C-Mn-Si TRIP steels. ISIJ Int. 1999, 39, 813-822. [CrossRef] 
13. Soliman, M.; Weidenfeller, B.; Palkowski, H. Metallurgical phenomena during processing of cold rolled TRIP steel. Steel Res. Int. 2009, 80, 57-65.

14. Barbé, L.; Verbeken, K.; Wettinck, E. Effect of the addition of P on the mechanical properties of low alloyed trip steels. ISIJ Int. 2006, 46, 1251-1257. [CrossRef]

15. Luzginova, N.; Zhao, L.; Sietsma, J. Evolution and thermal stability of retained austenite in SAE 52100 bainitic steel. Mater. Sci. Eng. A 2007, 448, 104-110. [CrossRef]

16. Jimenez-Melero, E.; van Dijk, N.H.; Zhao, L.; Sietsma, J.; Offerman, S.E.; Wright, J.P.; van der Zwaag, S. Characterization of individual retained austenite grains and their stability in low-alloyed TRIP steels. Acta Mater. 2007, 55, 6713-6723. [CrossRef]

17. Bhadeshia, H.K.D.H. Bainite in Steels: Transformation, Microstructure and Properties, 2nd ed.; Institute of Materials: London, UK, 2001; p. 9.

18. Garcia-Mateo, C.; Caballero, F.G.; Bhadeshia, H.K.D.H. Acceleration of low-temperature bainite. ISIJ Int. 2003, 43, $1821-1825$. [CrossRef]

19. García-Mateo, C.; Caballero, F.G.; Bhadeshia, H.K.D.H. Mechanical properties of low-temperature bainite. Mater. Sci. Forum 2005, 500-501, 495-502.

20. Peet, M.; Babu, S.S.; Miller, M.K.; Bhadeshia, H.K.D.H. Three-dimensional atom probe analysis of carbon distribution in low-temperature bainite. Scr. Mater. 2004, 50, 1277-1281. [CrossRef]

21. Tian, J.Y.; Xu, G.; Zhou, M.X.; Hu, H.J. Refined bainite microstructure and mechanical properties of a high-strength low-carbon bainitic steel treated by austempering below and above $M_{S}$. Steel Res. Int. 2018, 89, 1-10. [CrossRef]

22. Lan, H.F.; Du, L.X.; Zhou, N.; Liu, X.H. Effect of austempering route on microstructural characterization of nanobainitic steel. Acta Metall. Sin. (Engl. Lett.) 2014, 27, 19-26. [CrossRef]

23. Zaefferer, S.; Ohlert, J.; Bleck, W. A study of microstructure, transformation mechanisms and correlation between microstructure and mechanical properties of a low alloyed TRIP steel. Acta Mater. 2004, 52, 2765-2778. [CrossRef]

24. Kim, S.; Lee, C.G.; Choi, I.; Lee, S. Effects of heat treatment and alloying elements on the microstructures and mechanical properties of $0.15 \mathrm{wt}$ pct $\mathrm{C}$ transformation-induced plasticity-aided cold-rolled steel sheets. Metall. Mater. Trans. A 2001, 32, 505-514. [CrossRef]

25. Sadagopan, S.; Urban, D.; Wong, C.; Huang, M.; Yan, B. Formability Characterization of a New Generation High Strength Steels; TRP0012; Ispat Inland Inc.: Chicago, IL, USA, 2003.

26. Terrazas, O.R.; Findley, K.O.; Van Tyne, C.J. Influence of martensite morphology on sheared-edge formability of dual-phase steels. ISIJ Int. 2017, 57, 937-944. [CrossRef]

27. Karelova, A.; Krempaszky, C.; Werner, E.; Tsipouridis, P.; Hebesberger, T.; Pichler, A. Hole expansion of dual-phase and complex-phase AHS steels-effect of edge conditions. Steel Res. Int. 2009, 80, 71-77.

28. Tang, S.; Lan, H.; Li, J.; Liu, Z.; Wang, G. The role of microstructural constituents on strength-ductility-local formability of a transformation-induced-plasticity-aided bainitic steel. Steel Res. Int. 2020. [CrossRef]

29. Sugimoto, K.; Nakano, K.; Song, S.; Kashima, T. Retained austenite characteristics and stretch-flangeability of high-strength low-alloy TRIP type bainitic sheet steels. ISIJ Int. 2002, 42, 450-455. [CrossRef]

30. Jacques, P.J.; Delannay, F.; Ladrière, J. On the influence of interactions between phases on the mechanical stability of retained austenite in transformation-induced plasticity multiphase steels. Metall. Mater. Trans. A 2001, 32, 2759-2768. [CrossRef]

31. Yang, H.; Bhadeshia, H.K.D.H. Austenite grain size and the martensite-start temperature. Scr. Mater. 2009, 60, 493-495. [CrossRef]

32. Xiong, X.C.; Chen, B.; Huang, M.X.; Wang, J.F.; Wang, L. The effect of morphology on the stability of retained austenite in a quenched and partitioned steel. Scr. Mater. 2013, 68, 321-324. [CrossRef]

33. Chiang, J.; Lawrence, B.; Boyd, J.D.; Pilkey, A.K. Effect of microstructure on retained austenite stability and work hardening of TRIP steels. Mater. Sci. Eng. A 2011, 528, 4516-4521. [CrossRef]

34. Jimenez-Melero, E.; van Dijk, N.H.; Zhao, L.; Sietsma, J.; Wright, J.P.; van der Zwaag, S. In situ synchrotron study on the interplay between martensite formation, texture evolution and load partitioning in low-alloyed TRIP steels. Mater. Sci. Eng. A 2011, 528, 6407-6416. [CrossRef]

35. Jimenez-Melero, E.; van Dijk, N.H.; Zhao, L.; Sietsma, J.; Offerman, S.E.; Wright, J.P.; van der Zwaag, S. Martensitic transformation of individual grains in low-alloyed TRIP steels. Scr. Mater. 2007, 56, 421-424. [CrossRef]

36. Sugimoto, K.; Misu, M.; Kobayashi, M.; Shirasawa, H. Effects of second phase morphology on retained austenite morphology and tensile properties in aTRIP-aided dual-phase steel sheet. ISIJ Int. 1993, 33, 775-782. [CrossRef]

37. Taylor, M.D.; Choi, K.S.; Sun, X.; Matlock, D.K.; Packard, C.E.; Xu, L.; Barlat, F. Correlations between nanoindentation hardness and macroscopic mechanical properties in DP980 steels. Mater. Sci. Eng. A 2014, 597, 431-439. [CrossRef]

38. Yang, D.; Xiong, Z. The dependence of fracture resistance on the size and distribution of blocky retained austenite-martensite constituents. Metall. Mater. Trans. A 2020, 51, 2072-2083. [CrossRef] 